\title{
DIE AARD VAN DIE PERSOONLIKE TOESPITSING VAN DIE HEIL IN DIE HEIDELBERGSE KATEGISMUS
}

('N STEEKPROEF)

H. Dijkstra

\section{VRAAG}

\section{Probleemstelling}

Die begin, die inset, die uitgangspunt van denke en doen is (ook teologies) van die grootste betekenis. Daar is 'n samehang en wisselwerking tussen begin en einde, uitgangspunt en doelstelling. Daarom kan dit nuttig wees om jou krities op jou uitgangspunt te besin.

Kan wie begin met die vraag: „Of ek met sekerheid weet of ek hemel toe sal gaan as ek vannag te sterwe sou kom?", al is dit 'n diagnose-vraag, daarna nog uitkom by die bybelse boodskap van die Koninkryk van God volgens sy bybelse struktuur, m.a.w. by die Koninkryk van Gód wat nie eers deur my uitgangspunt begrens is nie?

Moét die prakties-pastorale voorkeur vir en beklemtoning van die vraag ,hoe weet ek of ek één van die uitverkorenes is?" (dié vraag van die Engelse puriteine en Skotse Calviniste sinds Perkins in die $16 \mathrm{e} e \mathrm{eu}$ ), nie lei tot 'n verskuiwing van wat God vir ons in Christus gedoen het na wat ons moet doen om te weet dat ons onder die uitverkorenes tel nie? ${ }^{1}$ Want waar en wanneer kom hierdie saak teologies-dogmaties aan die orde in die bybelse verkondiging? En is hierdie saak dan as 'n vraag (in die prinsipiële sin van die woord) aan die orde? En kan hierdie saak uit die verbande van die weg en werk van Christus en die Heilige Gees individualisties geïsoleer word?

Nou lyk dit asof die Kategismus ons voor dieselfde probleemstelling plaas. As die Kategismus naamlik vra: "wat is jou enigste troos in lewe en in sterwe?" en antwoord: „Dat ek met liggaam en siel, in lewe en in sterwe nie aan myself nie, maar aan my getroue Saligmaker Jesus Christus toebehoort, wat met sy dierbare bloed vir al $m y$ sondes ten volle betaal en $m y$ uit alle heerskappy van die duiwel verlos het, en $m y$ so bewaar dat sonder die wil van $m y$ hemelse Vader geen haar van my hoof kan val nie, ja ook, dat alles tot $m y$ saligheid moet dien; daarom verseker Hy $m y$ ook deur sy Heilige Gees van die ewige lewe en mak Hy my van harte gewillig en bereid om verder vir Hom te lewe."

Kan wie só begin by die: enkeling (... jou ... ek ... myself $\ldots$ my ... my ...my . . my . . my ...my . . my ... my . . my ...), sy heil (alles tot my saligheid) en sy sekerheid (verseker Hy my), nog uitkom by die eintlike dimensies en perspektiewe van die bybelse boodskap?

Hierdie dimensies en perspektiewe kan nouliks vanuit die horison van die enkele mens en sy saligheid en sekerheid ter sprake kom. 
Want kry ons dan nie pas in die tweede instansie met die naaste te doen nie, die naaste geskei van God ${ }^{2}$; en met die wêreld as die domein en mag waarteen ons beskerm moet word, waarin ons moed ingepraat moet word, hoogstens as evangelasieterrein waar die siele vir Christus gewin kan word en nie as God se wêreld. Sy koninkryksdomein nie. Gaan alles om my, on my en my saligheid en sekerheid? Is dit in ooreenstemming met die eerste vraag en antwoord van die Kategismus as Bernardus Smijtegelt daarby as eerste vraag vra: "Wat is het allermeest wenschelijk voor den mensch?" en antwoord: „Dat hij mogt zalig worden"? ${ }^{3}$.

Die probleemstelling word mooi deur $\mathrm{K}$. Barth onder woorde gebring:

"Ist wirklich dies, dass ich als Christ um Christi willen so gut, so herrlich dran sein darf, das letzte und eigentliche Ziel meiner Berufung, dann hängt für mich praktisch doch wohl Alles daran, dass ich mir dessen, dass ich in Kraft oder Schwachheit faktisch so daran bin, mit unüberwindlicher Bestimmtheid bewusst bin: Alles an meiner der ständig drohenden Verdunklung meiner Heilserfahrung überlegenen persönlichen Heilsgewissheit. Sicher darf, kann und soll der Christ seines Glaubens und seines Heils gewiss sein. Aber kann sein Heil als von ihm erkanntes das seine christliche Existenz beherrchende Prinzip sein: der Nagel, an dem er alles Ubrige aufzuhängen hätte? Kann es wohlgetan sein, wenn man ihm und wenn er er selbst einredet, von seiner persönlichen Heilsgewissheit her denken zu mussen und zu können?....

Sollte nun wirklich gerade das Selbstzweck, Sinn und Grund meiner christlichen Existenz undn so Ziel und Ende der Wege und des Redens Gottes mit mir sein: dass ich begnadigt, meine Seele errettet, ich aller Güter der Versöhnung teilhaftig, mein Leben ein Leben in ihrem Empfang, Besitz, Gebrauch und Genuss, ich schliesslich ,selig' werde - ich nicht in die Hölle, sondern in den Himmel komme, gewiss ich und einige, vielleicht auch viele Andere, aber auch was diese Anderen betrifft: dass es für Jeden von ihren zu der in jener Wohltat Christi vermiittelten ausserordentlichen Erhöhung seiner menschlichen Existenz und so zur Stillung seiner tiefsten Bedürfnisse, zur Erfullung seiner höchsten, notwendigsten Wünsche komme? Wonach schmeckt eigentlich dieses ganze possessive Wesen? Nun nicht doch nach Sanktionierung und Kultur einer in ihrer ganzen Heiligkeit tatsächlich álzu meschliche' Egozentrizität - einer Selbstsucht, neben der sich in anbetracht dessen, um was as da geht, alle sonstige menschliche Selbstsucht sehr harmlos ausnehmen könnte? Sicher gibt es auch ein christlich höchst legitimes und notwendiges ,Ich' und ,mein'. Aber geht es denn so: alles dieses gewiss herrliche ,Ich' und 'Mein' als letztes Wort über das, was den Christen zum Cchristen mach?" 4.

Barth wys wel daarop dat die probleemstelling in die geskiedenis meer kompleks is en dat die neiging tot verenging in die konsentrasie op die persoonlike heilservaring steeds met „glückliche Inkonsequenzen" gepaard gegaan het, soos dit o.a. blyk uit die begeleidende geweldige ekspansiedrang en opbloei van sending en evangelisasie. Maar hy vra:

„Könnte es nicht im Ergebnis umgekehrt eine Verstärkung, ja Potenzierung des frommen Egozentrusmus nach sich ziehen, wenn jenes Streben 
sich vom individuellen zum kollektiven erweitert - wenn sich, statt dass nur hier Dieser, dort Jener das tut, nun viele, ganze Gruppen und Korporationen gemeinsam mit dem Empfangen und Geniessen der beneficia Christi beschäftigen, und so beschäftigt an der Seite Gottes in der Welt der Welt gegenüber stehen wollen? Kann und wird jener Heilsegoismus in dieser Erweiterung sich nicht nur noch gewaltiger ausleben? Wenn schliesslich die ganze Christenheit, die Kirche nichts Anderes als eine gewaltige Heilsgemeinde und Heilsanstalt sein sollte!" s.

Hy sê: „... es scheint sich der fromme Egozentrismus des Einzelnen doch immer wenigstens $\mathrm{zu}$ einer Art Kollektiv-Egozentrismus erweitern zu müssen" ". Dan kry ons 'n selftevrede en selfgenoegsame Christendom en Christelike kerk, waarin dit in alle ywer alles nog steeds gaan om God en my saligheid. Iemand het gesê dat die basiese drif wat die mensdom beheers doodgewone vraatsug is. Nouja, ook in ons verhouding tot God is daar so iets soos vraatsug, hebsug. inhaligheid. Dan leef ons besitlik, egoisties, in selfbevrediging met God.

\section{Troos-motief reeds die probleem?}

Dit is duidelik dat die eerste vraag en antwoord van die Kategismus nie maar net ' $n$ inleiding tot die res van die Kategismus is nie. Die bedoeling van die eerste vraag en antwoord is om die héle belydenis saam te vat, om die hart en binneste kern van die héle christelike belydenis aan te dui. En dit doen die opstellers om die hele inhoud van die christelike leer onder die troos-motief saam te vat.

Die vraag is nou of dáárin nie alreeds 'n sekere verenging opgesluit lê nie.

K. Schilder wys daarop dat die vraag by herhaling gestel is: „wordt de Catechismus daarmee niet een boekje ván en óver en vóór den ménsch? Is dit boekjie niet, antropologisch', om niet te zeggen ,antropocentrisch'? D.w.z. draait hier niet alles om den mensch, is niet de mensch het einddoel, zijn geluk, zijn troost, zijn rust?" ? Die Nederlandse Geloofsbelydenis met sy teologiese opset is in hierdie opset dikwels teen die antroposentriese opset van die Kategismus uitgespeel. Schilder meen dat daar legitiem op twee maniere oor die verhouding van God en mens gepraat kan word: mens kan oor die mens praat i.v..m. God en oor God i.v.m. die mens. En as mens lg. manier (ten onregte) antropologies wil noem dan het hy tog geen beswaar daarteen nie. Die vraag is egter of die Kategismus inderdaad „,antroposéntries" spreek, of die mens in die middelpunt staan, die spil is waar alles om draai, die doel is, waarin alles uitmond.

Inderdaad, ,wie met ,God en goddelijke zaken'.... alleen daar. toe zich bezig houdt, dat hij toch maar getroost moge worden tegen wat hem zijn misère dunkt te zijn, die is een dienaar van zichzelf, een afgodendienaar, en vreemd aan het geloof ...." 8 .

Hét ons in hierdie troos-motief van die Kategismus met 'n subjektiewe innerlike belewingstoestand te doen? Iets van die mens, vir die mens; die mens wat weer tot homself moet kom; die religieuse 
subjek wat sy harmoniese ewewigsposisie weer moet herwin? Dan sou Schilder konkludeer: „Is eenmaal de troost tot een aangelegenheid van den mensch geworden die zijn ethisch en religieus evenwicht herkrijgen moet, dan kan zulk een troost voor geen ander dan een antropocentrisch denkgeheel tot grondmotief meer dienen" . Die hele opset ' $n$ probleem?

Karl Barth verbind die beskuldiging, dat die Kategismus in die rigting van antroposentrisme tendeer, aan die soteriologiese opset van die Kategismus: „Mann wird sagen dürfen, dass er ausgesprochen eine Theologie des dritten Artikels, eine Theologie des Heiligen Geistes, darstellt, aufgebaut unter dem besonderen Gesichtspunkt des Werkes Gottes am Menschen. Eine so orientierte Theologie steht in der Gefahr des Anthropozentrismus, d.h. des Abgleitens in eine einseitiges Interesse am Menschen, sodass Gott und die gottlichen Dinge bloss noch als Exponent menschlicher Erfahrung und menschlichen Erlebens erscheinen möchten" ${ }^{10}$.

\section{Probleemstelling reeds by Luther?}

Het mens by Luther, met name in sy gedagte van Christus as die scopus van die Skrif nie ook met dieselfde of 'n soortgelyke probleemstelling te doen as dié wat by die Kategismus gesuggereer is nie?

Die gedagte van Christus as die scopus van die Skrif vertoon by hom soms duidelike Skrifkritiese tendense. Dit is dan nie meer ,'n kriterium waaraan die evangeliese struktuur van die geloofs. kennis getoets kan word nie, nl. of dit die struktuur het van 'n belydenis Coram Deo nie, maar dit word 'n verrekenbare en hanteerbare teorie aan die hand waarvan die dogmatiese horison van die geloofskennis bepaal en christologies verhaal word, en dan wel christologies in 'n soteriologiese toespitsing. Vanuit hierdie (gereduseerde) dogmatiese horison kom hy dan tot 'n kritiek op bepaalde kanoniese boeke" 11 . Rossouw wys daarop dat Calvyn in teëstelling met Luther sy dogmatiese horison nie deur die leer van die regverdiging deur die geloof alleen laat vereng nie. . By Calvyn word die grense van die geloofskennis aangedui deur die dogmatiese tese: sola scriptura.

\section{ANTWOORD}

Sondag 1 in stryd met die res van die Kategismus?

In die eerste plek is daarop gewys, dat, as bogenoemde kritiek korrek sou wees, Sondag 1 dan in stryd is met die res van die Kategismus, met name met die drie dele wat die grootste deel van die inhoud uitmaak: die Apostoliese geloofsbelydenis, die tien gebooie en die Onse Vader. In die twaalf artikels gaan dit nie regstreeks oor die mens nie, maar oor God - God die Vader, die Seun en die Heilige Gees. In die tien gebooie gaan dit eers oor God en daarna oor die mens. En in die Onse Vader gaan dit ook eers driemaal oor God en daarna driemaal oor ons ${ }^{12}$.

Kyk maar weer na die Onse Vader, waarin die Here Jesus 
ons leer bid deur van onsself af weg te bid ${ }^{13}$. Hier word ons geleer dat die regte gebed ons van ons sondige beperking tot onsself bevry. Hier word ons eie-ek, ons egoisme verteer. Die inhoud van die Onse Vader is: die Koninkryk van God. Om reg te bid moet daar bekering, om-dink (andersomdink), omkeer in gesindheid plaasvind. Die Evangelie van die Koninkryk begin met die oproep: „Bekeer julle, want die Koninkryk van God het naby gekom." Daardeur verdwyn ons uit die middelpunt en kom daar iets anders in die middelpunt - die Koninkryk van God en sy geregtigheid. So kom alle ander groot en klein dinge te staan in die omvattende verbande van die Koninkryk. .

Hier is „ek" een van hulle wat sê: „onse Vader". My sorge, twyfel... verloor in die "Onse" Vader die knellende en benouende beperking tot my eie eensame ,ek". Ons begin dan met die bede om die heiliging van Gód se Naam, wat beteken dat ons heel eerste van God begeer dat Hy geëer en geprys word - dit weeg die swaarste. Dan vervolg ons met: "laat U koninkryk kom", waarby ons van die verhoring mag uitgaan ,want aan U behoort die Koninkryk". En daarna volg die bede, dat God se wil mag geskied, waarby ons dus van onsself afstand doen. Hier bid ons nie alleen van onsself af weg nie, maar selfs teen onsself in, want as God se wil geskied, beteken dit dat ons eie natuurlike wil nie geskied nie. In hierdie verbande gaan dit dan oor óns brood, óns skuld en ons versoekinge, en gaan die gebed oor in aanbidding en lofsegging. Hoe kan ons ooit hiér uitkom as jou uitgangspunt individualisties, antroposenties, heilsegoisties vereng was?

Mens kan nog verder gaan en beweer, dat indien die kritiek van heilsegoïsme op Sondag 1 korrek is, Sondag 1 dan met homself in stryd is: God wat alles gee (die bloed van Jesus Christus) en ons wat onsself handhaaf -

„Merkwürdiges Missverhăltnis,” se K. Barth, „zwischen der Selbstlosigkeit, ja Selbsthingabe Gototes und Jesu Christi, in der. das Heil der Welt verwirklicht und offenbart ist-und der Genügsamkeit, in der die Christen es sich nur eben recht sein und gefallen su lassen hätten, als seine Empfänger die Nutzniesser des so ganz anderen Seins und Tuns ihres Herrn zu sein!.... Welche sonstige menschliche Egozentrizităt wäre nicht entschuldigt, ja be stätigt und geweiht, wenn Egozentrizităt in dieser heiligen Abart der gottgewollte Sinn der christlichen Existenz sein, wenn deren Lobgesang schliesslich doch nur in dem ebenso vielstimmig wie monoton erklingenden Geschrei: pro me, pro me! und ähnlichen possessiven Äusserungen bestehen sollte?" 14 .

\section{Die betekenis van die „vraag"}

In die tweede plek moet ons kortliks aandag see aan die vraagstruktuur van die Kategismus.

Die vraagstruktuur van die Kategismus het geen prinsipiële betekenis in die sin dat alles werklik met 'n werklike vraag begin nie. Dit beteken nie dat die vraag sonder betekenis is nie. Inteendeel, die vrae wat jy vra, waarmee jy begin, wat jou uitgangspunt is, kan van die allergrootste betekenis wees. 
Vergelyk byvoorbeeld die vraag in Lukas $10: 25$ : „Meester, wat moet ek doen om die ewige lewe te beërwe?" Hoe kan ek in die hemel kom? Dit gaan vir hierdie wetgeleerde in sy godsdiens om homself, sy veiligheid, sy voorspoed, sy geluk en sy salige toekoms. En omdat die uitgangspunt van hierdie godsdienstige man hyself en sy eie klein wêreldjie is, bly sy volgende vraag "wie is my naaste?" ook tot hierdie wêreldjie beperk - hy vra die vraag om homself te regverdig! (vs. 29) Om sy eie vertroude godsdienstige opvattings te laat bevestig.

Ook kan 'n blote metodiese eerste vraag verder onbewus so 'n rol speel, dat die in feite die karakter van 'n prinsipiële "vraag" word.

Wat die Kategismus betref, moet mens in elk geval sê dat die vraag-antwoordstruktuur bloot prakties gemotiveer is: die leermeester vra die vrae en die leerling gee die antwoord as bewys daarvan dat hy die verbondsonderrig van die kerk met vrug gevolg het ${ }^{15}$.

Soms is die vrae ewe belangrik as die antwoorde. In die meeste gevalle (soos byvoorbeeld in Sondag 1) is die vraag net ,wegbereidster" 10 vir die antwoord, dien dit net om plek te mak vir die antwoord, word die vraag deur die antwoord bepaal en moet dit gevolglik nie te veel beklemtoon word nie.

'n Bekende voorbeeld is vraag en antwoord 15 van die Kategismus: „Hoedanig 'n middelaar en verlosser moet ons dan soek?" Die punt is: ons „soek" nie 'n middelaar, só 'n Middelaar nie - „daar is niemand wat God soek nie" (Rom. 3:11). Sondag 5 en 6 gaan in sy vraagstelling prinsipieel reeds uit van die antwoord wat eers op vraag 19 (,waaruit weet jy dit?") gegee word: „Uit die heilige evangelie...."

In ander gevalle (veral in die eerste deel van die Kategismus) is die vrae nie soseer die vrae wat die Bybel ons leer vra nie, maar is dit doodgewoon die vrae wat ons vra - menslike vrae, dikwels al te menslike vrae. Op hierdie menslike vrae word dan 'n bybelse antwoord gegee. Maar antwoorde wat logies nie klop met die vraag wat gevra is nie. Die feit dat dit so is, hoef ons dan glad nie te ontstel nie. Want enersyds is dit 'n onderstreping van die praktiese, pastorale, eksistensiële aanpak van die Kategismus en andersyds is die onlogiese antwoord die bewys dat die bybelse openbaring tog nie by die mens aangepas word nie, nie antroposéntries omgebuig word nie!

In hierdie verband kan ons na vraag en antwoord 9 verwys. „Die mens" in die vraag is die in sonde gevalle mens wat nie die eis van die wet kan nakom nie, terwyl "die mens" van die antwoord die mens voor die sondeval is.

\section{Die persoonlike kategorië̈ by die Reformasie}

In die derde plek hang die inset van die Kategismus saam met die religieuse konsentrasie en persoonlike kategorieë van die Reformasie.

Dink net wat dit vir die mense van die $16 \mathrm{e}$ eeu beteken het, die besef dat die Christelike leer hulle werklik persoonlik ${ }^{17}$, „,eksistensieel" aangaan. 
In die Roomse Kerk het hulle vereensaam en verkommer, omdat die waarheid versaaklik en verkerklik is. Sinds die Middeleeuse skolastiek is die versoening deur Christus in die kaders van die verdiensteleer ingebou. En die kerk het oor die verdiensteskat beskik. Daarteenoor het die Reformatore die evangelie van plaasvervanging, van Christus vir ons geplaas ${ }^{18}$. Hier staan ek, persoonlik, onbemiddeld in die lig en warmte van die Openbaring van God in Jesus Christus - die lig uit die hoogte! Dit is iets geweldigs!

En hierdie konsentrasie van die Reformasie het hoegenaamd nie beteken dat die heil tot wat met my persoonlik gebeur gereduseer is en dat die mens uit die volle geskape werklikheid geïsoleer is nie! Dit is nie die Reformasie nie, maar histories 'n na-Reformatoriese ontwikkeling wat die heilsgeskiedenis tot 'n sielsgeskiedenis gereduseer het, met alle gevolge daarvan.

Reeds die Piëtisme het die orde omgekeer en die bevinding aan die geloof ten grondslag gelê ${ }^{19}$. Die gevolg daarvan was dat die vromes hulle met hulself besig gehou het, saamgekom het om oor "geestelike dinge" te praat en die wêreld aan sy eie lot oorgelaat het. Vir die piëtistiese Christene, sê H. Bavinck, was ,het godsdienstige, het geestelijke leven .... het eenig ware leven, en drong alle andere arbeid als van veel mindere waarde terug. Men had nu eenmaal wel een man, eene vrouw, een gezin, een beroep in de maatschappij, en men moest er eenige zorg aan wijden. Maar men deed het met zeker gevoel van tegenzin, het stond in scherp contrast met het geestelijk leven, het scheen altijd min of meer een dienen der wereld te zijn; in elk geval het was een leven van lagere orde en van minderen rang. Neer te zitten in stille overpeinzing, of in den kring der vromen te vertellen, wat God aan de ziel had gedaan - dat was het ware leven, dat het ideaal van den vrome, dat de bestemming van den Christen" ${ }^{20}$.

Maar sedert Kant kry die pro me- of pro nobis-kategorieë van die Reformasie die formele betekenis van 'n kenteoretiese prinsipe waardeur skeiding gemaak is tussen die objektiewe en subjektiewe, algemene en individuele, dogmatiese en eksistensiële, leer en lewe, teoretiese en praktiese, oninteressante en interessante, metafisiese en persoonlike ${ }^{21}$. Nou word pro me ,'n aanduiding van die ontiese modus van die Openbaringswaarheid. Daarmee word nl. die subjektiwiteit van die Openbaringswaarheid tot uitdrukking gebring in onderskeiding van alle objektiewe algemeenheid. Die Openbaringswaarheid bestaan alleen in sy praktiese funksionaliteit vir die individuele gelowige.... Waarom dit gaan, is die feit dat die me van die pro me hier dui op die individuele ek en dat die ontiese modus van die Openbaringswaarheid resloos bepaal word vanuit die subjektiwiteit van hierdie individuele ek" ${ }^{22}$.

Die reduksie-proses wat hiermee aan die gang gesit is, wat tot in die moderne Teologie voortgaan, word deur Bavinck soos volg onder woorde gebring: Hierdie metode ,is een stille verzuchting, dat de wetenschap het binnenste heiligdom des gemoeds moge ontzien en daar de plant der religie ongemoeid late tieren. Zij wil alles, de gansche wereld, de natuur, de geschiedenis en bijna den geheelen mensch met zijn gewaarwording en waarneming, geheugen 
en verbeelding, verstand en rede aan de positivistische wetenschap overlaten, mits het haar gegund zij om ergens diep in het hart van den mensch een kleine, bescheidene plaats voor het geloof te behouden. En daarom geeft zij bolwerk na bolwerk prijs, laat de emancipatie en secularisatie zelfs toepassen op verreweg het grootste gedeelte der theologie en der dogmatiek" ${ }^{23}$.

Vir die Reformatore het die saaklike leerinhoud van die Openbaringswaarheid sélfs egter 'n pro me of 'n pro nobis struktuur. „Die is intrinsiek gerig op die besondere bestaan van die konkrete mens.... Die pro nobis bring .... tot uitdrukking dat dit tot die saak self behoort dat dit $\mathrm{nl}$. betrokke is op die konkrete mens" ${ }^{24}$. Dit is dus ook nie 'n subjektiese aksent wat agterna aan die objektiewe waarheid toegevoeg moet word nie. Nee, hierdie pro me is inherent aan, onlosmaaklik een met die Evangelie van Jesus Christus self. Jesus is oorgelewer ter wille van ons misdade en opgewek ter wille van ons regverdiging (Rom. $4: 25$ )!

Hier blyk dat mens die „pro nobis" en ,extra nos" van die heilsdade nie uilmekaar mag torring nie. Die pro nobis gespeen van die extra nos, moet inderdaad tot heilsegoisme en 'n versmalling van die Openbaringswaarheid lei - wat ek nie vanuit my eie belewingshorison kan plaas nie, word soos 'n blindederm afgesny; en wat nie deur die sif van die sielservaring gaan nie, word stukkie in die sekularisasieproses prysgegee.

Daarvan kan ons die Reformasie met sy klem op die pro me en die Kategismus as produk van die Reformasie met sy persoonlike toespitsing egter nie beskuldig nie. Ons mag die Kategismus nie onhistories in die lig van 'n na-Reformatoriese ontwikkeling verklaar nie. In die eerste antwoord van die Kategismus word ek vir "my troos" verwys na Christus aan wie ek behoort, wat vir my met Sy dierbare bloed betaal en my uit die heerskappy van die duiwel verlos het - ons word ,bei der Frage nach diesem gleichsam ,subjektiven', nach ,meinem Trost', sogleich auf die Gotteswirklichkeit extra nos verwiesen" ${ }^{25}$ Wat die huidige betref is dit goed om weer daaraan te herinner: „Das pro me gehört ins Evangelium. Indem so der Inhalt, die Lehre, wieder bestimmend wird für die Methode des Erkennens, vollzieht sich die Befreiung der Dogmatiek aus den Fesseln, die ihr der erkenntnistheoretische Formalismus unter Misbrauch des Pro me angelegt hat" ${ }^{20}$.

\section{Die „ek” van die Kategismus}

Nou kan ons (in die vierde plek) aandag gee aan die „ek" van die Kategismus.

Hierdie „ek" is nie die individuele empiriese ek, die moderne mondige eensame enkeling-mens nie. Hierdie „ek" is nie 'n ,anonieme subjek op wie die waarheid van die Woord toegepas moet word nie", maar hierdie „ek" is die "me" van die reformatoriese pro me ,.,wat van alle ewigheid af behoort by die Woord, die ek wat in die Woord by sy naam geroep word uit die anonimiteit van 'n eensame verlorenheid tot die gemeenskap van die Vaderhuis, tot die gemeenskap van Gods volk. (En) die ,ons' van die pro nobis 
is die ons waartoe ek behoort. Dit is die ons van die ekklesia, van die uitverkore geroepenes. Dit is die ons van hulle vir wie die Woord geld, van hulle wat as hoorders aan die Woord toebehoort" ${ }^{27}$. Ons moet dus nie oor die persoonlike voornaamwoorde van die Kategismus struikel nie. Ook in die Apostoliese Geloofsbelydenis is dit „ek" wat glo, maar ek bely die geloof van die kerk van die eeue, met wie „ek" dan één is ${ }^{28}$. So is die „ek" van die Kategismus ook lid van die kerk ${ }^{29}$. Dit is die „ek" wat nie aan homself behoort nie (1 Kor. 6:19), maar aan die Here (Rom. 14:7, 8), wat van Christus is ( 1 Kor. $3: 23$ ). Dit is die „ek" wat deur die geloof in Hom ingelyf (vr. 20,80), ingeplant (vr. 64), lid van Christus is (vr. 32, 49, 70, 85), deelneem aan Christus (vr. 32, 53, 65), gemeenskap het met Christus (vr. 55), met Sy heilige liggaam verenig is (vr. 76) ${ }^{30}$.

Vandaar dat die ek -en ons-vorm in die Kategismus mekaar voortdurend afwissel ${ }^{31}$. Alle gelowiges saam en elkeen afsonderlik staan in gemeenskap met die Here Jesus Christus en elkeen is verplig om die gawes wat hy ontvang vrywillig en met vreugde tot nut en heil van die ander lede van die liggaam aan te wend (vr. 55) ${ }^{32}$.

„Ich existiere ekzentrisch, ich gehöre diesem Anderen", verklaar Karl Barth 33 .

„Ik kan pas mijzelf zijn, als ik niet meer van mijzelf ben" (Miskotte) ${ }^{34}$. "Voor mij is hier geen zelfstandige plaats meer", sê Miskotte), „ik ben Christus' eigen geworden; toch heb ik een plaats, door Hem bereid, om mij-zelf te zijn, juist nu ik van mij-zelf niet meer ben Wie zijn leven verliest, heeft het behouden" ${ }^{36}$.

\section{Pas op vir onbybelse teëstellings}

Dit moet op hierdie stadium (in die vyfde plek) wel duidelik wees dat mens baie versigtig moet wees om in jou beoordeling van die persoonlike toespitsing nie te kom tot onbybelse teëstellings, tot die konstruksie van 'n onbybelse konkurrensie-verhouding tussen: die bopersoonlike en persoonlike, die heilshistoriese en heilsordelike, die teologiese en antropologiese - tussen God en mens nie. Die persoonlike is opgeneem in die bopersoonlike, die heilsordelike in die heilshistoriese en die antropologiese in die teologiese.

Miskotte praat bv. van „Een heel persoonlijk weten, geborgen in een bóvenpersoonlijke wetenschap.... ${ }^{36}$.

Ons het ook gesien dat Schilder bv. geen beswaar het om ,antropologies" oor God in verband met die mens te spreek nie ${ }^{37}$. Hy verklaar dat die protes teen ,antropologiserende" tendense in die Kategismus „toch in werkelijkheid hierop neerkomen, dat éen der schoonste ,vreugden', die Gods kind in Christus hebben mag, ons wordt ontnomen" 38 .

Daar is trouens op gewys dat Sondag 1 self die teëstellings tussen liggaam en siel, lewe en sterwe, klein en groot, gelukkig en ongelukkig, wat God doen en wat ek doen, deurbreek ${ }^{39}$. 
"Troos"

Ons moet nou (sesdens) antwoord op die vraag of die "troos" van die Kategismus die grondmotief van 'n antroposentriese denkgeheel is. Het ons in hierdie "troos" met 'n subjektiewe innerlike belewingstoestand te doen? Gaan dit oor 'n innerlike behoefte aan troos a.g.v. die ellendes van die lewe?

„Men meent," sê Miskotte, „dat hier een antwoord beproeft wordt op de vraag, die opkomt uit 's mensen behoéfte aan troost. Misverstand! déze troost hebben wij niet gezocht, zij is gekómen; $z e$ is Gods ongevraagde werk; ze is de glans, die van de waarheid Góds uitgaat. Juist deze aanvat geeft Gode alleen de eer, d.w.z. niet aan een abstracte soevereiniteit, maar aan Hem, die in Christus was de wereld met Zichzelven verzoenende" ${ }^{40}$.

Hierdie troos moet ons nie sentimenteel verstaan, as iets wat ons moet voel nie. Nee, ,de troost rust.... op de wetenschap van het geloof .... De Waarheid is practisch; de wetenschap geeft troost; wetenschap is meer dan ervaring" ${ }^{11}$.

Vra mens of dit wel goed is om alles in die raamwerk van die troos te plaas, of dit moontlik is sonder om antroposentries te raak, dan antwoord $K$. Schilder: „Binnen de kerkmuren.... is er geen enkel bezwaar tegen, dat Gods werk bezien word als troostend, of zelfs, dat het onder het troost-motief wordt saamgevat. Want over God hebben we niet te spreken, tenzij dan in samenhang met de werken, die Hij heeft gedaan, en waarin Hij ons zich heeft bekend gemaakt" 42 .

Alles hang daarvan af hoe die begrip „troos" omskryf word. Want hierdie woord het in die loop van die eeue in die kommen. tare op die Kategismus 'n lydensgeskiedenis deurgemaak.

Schilder verduidelik: „Abraham troost zich in zijn offergang, want de ,hoofdsommen' van belofte en eisch treden in hun breeduiteengeledge verbanden hem voor de aandacht. Hij denkt aan 't verleden; toen Sara en hijzelf ,graven' waren, die echter naar de belofte opengingen (Rom. $4: 17$ ). In het verlengde van deze belofte-vervulling in het verleden denkt hij zich $66 \mathrm{k}$ de toekomst: zou o6k Izaks graf niet opengaan? Hij ,ziet' zoowel kerst- als paaschrealiteiten gloren (Joh. 8:56; Hebr. 11:18); Hij heeft de scheppings- en de herscheppingswerken Gods gezien en overwogen (Rom $4: 17$ ) en - op zichzelf betrokken. Dat is wat anders, dan.... op een bepaald punt phychisch te worden gerestaureerd" 43 . "Als de Heidelbergsche Catechismus zijn hoofdsommen opneemt in het kader van den christelijken troost, .... dan krijgen we te doen met de dramatiek van God en Satan, ja, van God, die zich door zijn eigen Zoon den schuldigen zondaar uit de rechtershand laat wegkoopen, en aan het Vaderhart laat leggen. Dan wordt de mensch niet over zich getroost door zichzelf, maar over dood, en breuk, en zonde, in en door het leven, dat geopenbaard, de genade, die geschonken, en de gerechtigheid, die aángebracht is door God in Christus" 14.

In die bybelse spraakgebruik en in die Kategismus het die woord "troos" in elk geval baie meer objektiewe betekenis as by ons. Dit is in Jes. 40 bv. iets wat toegeroep, verkondig moet word. 
En in Joh. $14: 15,16$ is die „troos" van die Trooster regsbystand vir die oortreder. Dit waarmee getroos word volgens die Kategismus (vir al my sondes tenvolle betaal.... uit alle heerskappy van die duiwel verlos.... geen haar van my hoof .... alles tot my saligheid dien ....) gaan eenvoudig bo my belewing uit! Dit gaan dan ook om die enigste (,eenige", unica) troos!

\section{„Die proef op die som" 45}

Die proef op die som, die deurslaggewende bewys dat die Kategismus die mens nie in die middelpunt plaas nie, is ten slotte die formulering van die antwoord self ${ }^{48}$ : „dat ek nie aan myself nie, maar aan my getroue Saligmaker Jesus Christus toebehoort", wat daarop uitloop dat ek „vir Hom lewe”. As ek nie aan myself nie, maar aan Christus behoort, dan het my lewe 'n ander middelpunt gekry ${ }^{47}$. Nie meer 'n lewe waarin alles om my „eie ek" draai nie, maar 'n lewe met Christus in die middelpunt. En as my lewe in Christus 'n ander middelpunt gekry het, dan ook 'n ander rigting en beweging. Nie meer op myself gerig nie, maar van harte gewillig en bereid om vir Hom te lewe - ek lewe van myself af weg! Hy het my juis bevry van my stilstand by myself, van my eensame en benouende sirkelgang in myself, van die vervreemding en vereensaming van my bestaan. Daarvan is ek bevry en ek is lid van die liggaam van Christus en het deel aan Sy salwing, deel in die sending en beweging deur die tyd. Saam met Hom is ck gerig op die naaste en die wêreld, die nuwe skepping. Wie nie meer aan homself behoort nie, is totaal beskikbaar vir God en sy naaste. En wie werklik beskikbaar is, is werklik vry. Sonder 'n eie selfbeeld om te verdedig, 'n eie status om te handhaaf, 'n eie ambisie om te bevredig, 'n eie sin en wil om teen elke prys deur te dryf. Dit is geen uitwissing van jouself nie. Inteendeel, jy vind jouself eers as jy jouself verloën en nie meer krampagtig oor jouself geboë sit nie! Dan leef ek nie meer nie, maar Christus leef in my: „Ich habe an dem Andern meine Grenze, bin durch Ihn begrenzt und begründet. Ich habe in Ihm meine eigentliche Transzendenz" ${ }^{48}$. Solank alles om myself draai, ek in die middelpunt bly, dan bly alles in die individueel-persoonlike sfeer van „ek en my saligheid" vassteek. Maar wanner ek nie meer aan myself behoort nie, dan kan die laaste sinnetjie van die Kategismus (vir Hom lewe), nie van die groot genade van die vorige sinnetjie oor "my saligheid" losgemaak, afgesny word nie - op straffe van: dat dié heil in die (kollektiewe) heilsegoissme sterf!

„Niet dat men om mij heencirkelt in de kerk als heils-instituut, maar dat ik Hém voortaan ga dienen, daarop loopt het antwoord uit" 48.

„De heilsgeschiedenis is hier niet in het slop van een privatissimum der ziel met God doodgelopen" so.

Der Katechismus redet gewaltig davon, wie Gott fur den Menschen ist, aber man darf nicht vergessen, wie da umgekehrt zuerst der Mensch als für Gott in Anspruch genommen erscheint" ${ }^{11}$. 


\section{Ten slotte}

Die geskiedenis leer ons dat die uitweg uit 'n situasie van versaakliking, veruitwendiging, onsekerheid, nie gevind word deur 'n beperking van die dogmatiese horison deur die leer van die regverdiging (Luther) nie, ook nie deur 'n konsentrasie op die vraag na die persoonlike heilsekerheid (Piëtisme) nie, of deur wat ook al tot die rang van 'n metodiese prinsipe verhef word en die teks van die Skrif met 'n ,heuristischen Kanon" behandel en vereng nie ${ }^{52}$, maar in die bekering tot en lewende-persoonlike verhouding met die lewende God self, wat Hom in die hele Skrif, waarvan Christus die scopus is, geopenbaar het (Calvyn) ${ }^{53}$ - in die bekering tot die Koninkryk van God en sy geregtigheid.... en al hierdie dinge van ons persoonlike heil en sekerheid en belewing daarvan sal vir ons (,,als een toegift" ${ }^{54}$ ) bygevoeg word.

En wanneer mens in die konkrete homiletiese, kategetiese of pastorale situasie vrae stel, wanneer jy byvoorbeeld jou uitgangspunt neem in die konkrete, persoonlike, menslike omstandighede van onsekerheid, dan sal dit gedoen moet word soos in die Kategismus, waar hulle ingebed lê in die breë verbande van die allesomvattende werk van Christus, die Koning („vir Hom lewe"). En dat ons ons daarmee laat troos dat ons aan Hom behoort - 'n troos wat tegelyk „Zuspruch" én „Anspruch" én „Ausrichtung" is "

Barth wys daarop en illustreer dit met talle Bybelse voorbeelde: "Allen biblischen Berufungsgeschichten ist das gemein: Berufenwerden heisst Auftrag bekommen .... Es ist also nicht so, dass, sie, nachdem sie ihn bekommen, fortfahren könnten, irgendwie an sich und für sich zu existieren, um sich dann unter anderen auch noch seiner Ausführung zu widmen. Indem sie ihm bekommen, werden sie selbst $i \mathrm{hm}$ gewidmet, kann also ihre Existenz gerade nur noch vom willen zu seiner Ausführung beherrscht sein, muss ihnen Alles, was sie als Menschen sind und haben, wollen und tun, ins zweite Glied rücken, der Ausführung ihres Auftrags untergordnet und diensbar werden ${ }^{\mathrm{s}}$.

En hierdie opdrag is om getuie te wees - om as getuie te sê wat God self hulle voorgelê het ${ }^{57}$.

Dit is die antwoord in die prediking van die Here Jesus: bekeer julle, want die Koninkryk van die hemele het naby gekom. Dink anders en draai om! Deur vir jouself te lewe in talle variasies, word jou lewe sinloos, maar deur jou te bekeer, begin jy om saam te werk aan God se werk en om die lewe die moeite werd te maak: „Een volwaardig leven is dus een leven dat niet om zichzelf cirkelt, dat in open relaties staat met de anderen, dat zich door een ander leven in beslag laat nemen ...." 88 . 'n Lewe van navolging, van Hom wat sê: Kom, ek het jou nodig!

\section{VOETNOTAS}

1 James B. Torrance: Calvin and Puritanism in England and Scotland. Voordrag Calvynkongres 1980, p. 14.

2 Vgl. egter O. Noordmans: Gods Poorten. 's-Gravenhage 1949, p. 36 e v. In die Bybel gaan dit nie soseer or "God en mens" (-onsself) nie, maar oor 
God en die naaste: „.... achter God en met Hom komt de hele bende op ons af en de God die alléén komt, is niet de Vader van onze Here Jesus Christus" (p. 37).

3 Bernardus Smijtegeld: Maandagsche Katechisatiën naar het beloop van den Heidelbergsche Catechismus. Nijkerk 1858, pp. 1.

4 Karl Barth: Die Kirchlicher Dogmatik. IV, 3 (Die Lehre von der Versöhnung). Zürich 1959, p. 649-651

5 idem, p. 655.

6 idem, p. 654.

7 K. Schilder: Heidelbersche Catechismus. I. Goes 1947, p. 14.

8 idem, p. 18.

9 idem, p. 24.

10 Karl Barth: Die christliche Lehre nach dem Heidelberger Katechismus. Zürich 1948, p. 19.

11 H. W. Rossouw: Klaarheid en interpretasie. Enkele probleemhistoriese gesigspunte in verband met die leer van die duidelikheid van die Heilige Skrif. Amsterdam 1963, p. 193.

12 Vgl. K. Schilder, a.w., p. 16.

13 Vgl. H Veldkamp: Beslagen vensters. Kampen 1954, p. 15 e.v.; vgl. ook Karl Barth: Das Vaterunser nach den Katechismen der Reformation, Züruch 1965.

14 Kirchliche Dogmatik, a.w., p. 651.

15 Th. L. Haitjema: De Heidelbergse Catechismus als klankbodem en inhoud van het actuele belijden onzer kerk. Wageningen 1962, p. 15.

16 J. G. Woelderink: De inzet van de atechismus. Verklaring van de zondagen I-VII van de Heidelberger. Franeker s.j., p. 11.

17 H. Veldkamp: Zondagskinderen. Franeker s.j. 4e druk, p. 7, 8: i.p.v. die onpersoonlike neutrale „die" troos, die warm persoonlike „jou" troos.

18 Vgl. Th. L. Haitjema, a.w., p 19.

$19 \mathrm{Vgl}$. James B Torrance, aangehaalde voordrag, p. 14 met verwysing na R. T. Kendall: Calvin and English Calvinism to 1649. O UP. 1979.

20 H. Bavinck: De zekerheid des geloofs. Kampen (1901) 19183, p. 99-100.

21 H. J. Iwand: Wider den Misbrauch des „pro me" als methodisches Prinzip in der Theologie. Evangelische Theologie. Jg. 1954, p. 453-458.

22 H W. Rossouw, a.w., p. 203; vgl. Walter Kreck: Das reformatorische „pro me" und die existentiale Interpretation heute. In: Studien zur Geschichte und Teologie der Reformation. Festschrift für Ernst Bizer. Herausgegeben von Luise Abramowski und J. F. Gerhard Goeters. Neukirchen 1969, p. 283 e.v.

23 H. Bavinck, a.w., p. 78.

24 H. W. Rossouw, a.w., p. 203-204; vgl G. C. Berkouwer: Subjectivisme noch objectivisme. In: Gereformeerd Weekblad XIV, 28 (9:1:59), p. 217.

25 Heinrich Ott: Dogmatik und Verkündigung. Ein Programm dogmatischer Arbeit, dargestellt im Anschluss an die Fragen 1 bis 11 des Heidelberger Kategismus. Zürich 1961, p. 40.

26 H. J. Iwand, a.a., p. 458.

27 H. W. Rossouw, a.w.., p. 204.

28 J. G. Woelderink, a.w., p. 12.

29 S. G. de Graaf: Het ware Geloof. Kampen 1954, p. 11; K. H. Miskotte: De blijde wetenschap. Franeker s.j., 2e druk, p. 12; Th. L. Haitjema, aowó p. 15,16 wys op die prioriteit van die gemeenskap en op die leerling wat 
kragtens die genadeverbond die geloof van die gemeente bely; vgl. ook F. Boerwinkel: Inclusief denken. Hilversum (1966) 197012, p. 27 e.v.

30 Vgl. Heinz Otten: Das Bekenntnis der Einheit der Kirche nach dem Heidelberger Katechismus. In: Evangelische Theologie V .Jg. (1938), p. 223 e.v.; Karl Barth: Das Vaterunser, p 15, 40 e.v., 76 e.v.

31 K. Exalto: De enige Troost. Inleiding tot de Heidelbergse Catechismus. Kampen s.j., p. 105; vgl. F. Boerwinkel, a.w., p. 90: „Het ,ik' kan niet tot vervulling komen zonder het ,gij'. Het zelf kan geen ,zelf' zijn zonder andere ,zelven',"

32 Vgl. Pierre Ch. Marcel: Die Lehre von der Kirche und den Sakramenten. In: Handbuch zum Heidelberger Katechismus Hrsg. Lothar Coenen, Neukirchen 1963, p. 138-139.

33 Karl Barth: Die christliche Lehre, p. 24.

34 By Th. Delleman. In: Alles in Hem. Nieuwe Commentaar Heidelbergse Catechismus I. Aalten s.j, (1966), p. 43, met verwysing na die huwelik.

35 K H. Miskotte, a.w.. p. 20.

36 idem, p. 12

37 K. Schilder, a.w., p. 15.

38 idem, p. 18.

39 K. H. Miskotte, a.w., p. 16 e v.; vgl. Th. Delleman in a.w., p. 44 e.v.

40 K. H. Miskotte, a,w., p. 10.

41 idem, p. 11/12; vgl. Karl Barth: Inleiding in den Heidelbergschen Catechismus. Nijkerk s.j (oorspr. 1938), p. 5/6.

42 K. Schilder, a,w., p. 18.

43 idem, p. 22.

44 idem, p. 26.

45 Formulering van $K$. Schilder, a.w., p 33.

46 K. Exalto, a.w., p. 63.

47 H. Veldkamp: Zondagskinderen, p. 13.

48 Heinrich Ott, a.w., p. 41.

49 K. Schilder, a.w., p. 46.

50 idem, p. 50.

51 Karl Barth: Die christliche Lehre, p. 19.

52 Vgl. Kar lBarth: Die Kirchliche Dogmatik. 1,2 Die Lehre vom Wort Gottes. Zürich 1948, p. 968 oor die rol wat die onderskeiding tussen fondamentele en nie-fondamentele geloofsartikels tydens die hoog-ortodoksie gespeel het.

53 Vgl. H W. Rossouw, a.w., p, 193 e.v. Calvyn begin sy Institusie en sy Kategismus van Genéve dan ook met die vraag: wat die belangrikste doel van die menslike lewe is, en antwoord: om God te ken! Vgl. Thomas F Torrance: The school of faith. London 1959, p. 5.

54 K H. Miskotte, a.w., p. 11.

55 Karl Barth: Kirchliche Dogmatik. IV, 3, p. 618 .

56 idem, p. 658 , vgl. p. 662 e.v.

57 idem, p. 660,661 .

58 Helmut Gollwizer: De dood heeft niet het laatste woord. Baarn 1975, p. 11; vgl. ook van Gollwitzer: Over de zin van het leven. Kampen 1974 (oorspr. Duits: Krummes Holz - Aufrechter Gang. Munchen 1970). 